\title{
The Effect of Monosaturated and Polyunsaturated Fatty Acids on Oxygen Toxicity in Cultured Cells
}

\author{
DOUGLAS R. SPITZ, MICHAEL T. KINTER, JAMES P. KEHRER, AND ROBERT J. ROBERTS \\ Division of Neonatology, Departments of Pediatrics [D.R.S., R.J.R.] and Pathology [M.T.K.], University of \\ Virginia, Charlottesville, Virginia 22908 and Division of Pharmacology and Toxicology, College of Pharmacy, \\ University of Texas, Austin, Texas 78705 [J.P.K.]
}

\begin{abstract}
The influence of oleic, linoleic (LIN), and eicosapentaenoic (EPA) acids incorporated into cellular lipids on susceptibility to $\mathrm{O}_{2}$-induced toxicity was evaluated in Chinese hamster fibroblasts (HA1) using a clonogenic cell survival assay. Fatty acid incorporation was achieved by incubating $\mathrm{HA1}$ cells in $21 \% \mathrm{O}_{2}$ for $72 \mathrm{~h}$ in the presence or absence of media supplemented with $25 \mu \mathrm{M}$ oleic acid, $25 \mu \mathrm{M}$ LIN, or 2,4 , and $25 \mu \mathrm{M}$ EPA. This fatty acid incorporation period increased the percentage of composition in phospholipids 2-fold for oleic acid, 6-fold for LIN, and 6- to 20-fold for EPA. Vitamin E, total glutathione, superoxide dismutase activity, glutathione transferase activity, and catalase activity were unchanged, relative to control, in the 25- $\mu \mathrm{M}$ EPA-treated group, and only total glutathione was elevated in the LIN-treated group. After the incorporation period, the cells were placed in non-fatty acid supplemented media and exposed to $95 \% \mathrm{O}_{2}$, and clonogenic survival responses were evaluated at time intervals up to $100 \mathrm{~h}$. Sensitization to $\mathrm{O}_{2}$ toxicity in EPAtreated cells was apparent after $24 \mathrm{~h}$ of $\mathrm{O}_{2}$ exposure, whereas LIN-treated cells were significantly $(p<0.05)$ sensitized to hyperoxia after $54 \mathrm{~h}$ of exposure, indicating that EPA was a more potent sensitizer for $\mathrm{O}_{2}$ injury. Furthermore, cells supplemented with 4 and $25 \mu \mathrm{M} \mathrm{EPA}$ were more sensitive to $\mathrm{O}_{2}$ toxicity than cells supplemented with $2 \mu \mathrm{M}$ EPA. In contrast, cells treated with $25 \mu \mathrm{M}$ oleic acid were significantly more resistant to $\mathrm{O}_{2}$ toxicity at 51, 72, and $98 \mathrm{~h}$ of $\mathrm{O}_{2}$ exposure. The results indicate that incorporation of polyunsaturated fatty acids (LIN or EPA) into the lipids of cultured cells enhances the cytotoxicity associated with exposure to $95 \% \mathrm{O}_{2}$, whereas incorporation of a monosaturated fatty acid (oleic acid) reduced the cytotoxicity of $95 \% \mathrm{O}_{2}$. These results suggest that $\mathrm{O}_{2-}$ induced injury can be modified by alterations in peroxidizable substrates present in cells. (Pediatr Res 32: 366-372, 1992)
\end{abstract}

\section{Abbreviations}

LIN, linoleic acid

EPA, eicosapentaenoic acid

PUFA, polyunsaturated fatty acid

DBI, double bond index

Received October 18, 1991; accepted April 30, 1992

Correspondence: Douglas R. Spitz, Division of Neonatology, Department of Pediatrics, University of Virginia, MR-4 Room 3033, Charlottesville, VA 22908. Supported by NIH Grants HL42057, DK38942, HL40695, and RR05431, and a grant from the University of Virginia Pratt Foundation.

Presented in part at the American Pediatric Society/Society for Pediatric Research meeting, New Orleans, LA, April 29-May 2, 1991.
Exposure to elevated $\mathrm{O}_{2}$ concentrations is thought to give rise to the overproduction of reactive $\mathrm{O}_{2}$ species, such as superoxide, hydrogen peroxide, and hydroxyl radical, which have been hypothesized to contribute to the injury process associated with $\mathrm{O}_{2}$ toxicity (1-4). Previous studies in animal models and in cell culture systems have suggested that reactive $\mathrm{O}_{2}$ species produced during exposure to hyperoxia may interact with noncritical PUFA, sparing critical cellular constituents such as proteins, DNA, and RNA from the damaging effects of interaction with reactive $\mathrm{O}_{2}$ species (5-9). Based on this theoretical concept, these authors hypothesized that an increased amount of PUFA in cells during exposure to hyperoxia might protect the cells from the injury produced during exposure to hyperoxia. The present studies were designed to specifically address this hypothesis using a previously characterized cell culture $\mathrm{O}_{2}$-toxicity model $(10)$ and specific polyunsaturated and monosaturated fatty acids.

In our studies, HA1 Chinese hamster fibroblasts were used and clonogenic cell survival was measured as the $\mathrm{O}_{2}$-toxicity end point. HA1 cells were incubated with media containing purified oleic acid, LIN, or EPA to incorporate these specific fatty acids into the cellular lipids. The specificity and extent of fatty acid incorporation was quantitated using gas chromatography. The vitamin $\mathrm{E}$ and cellular antioxidant status of the cells with and without PUFA (LIN, EPA) incorporation was evaluated before $\mathrm{O}_{2}$ exposure. Finally, the loss in cellular clonogenic potential as a function of time in $95 \% \mathrm{O}_{2}$ was evaluated in fatty acid supplemented and unsupplemented cells. The objective of these experiments was to evaluate the effect of specific fatty acid alterations on $\mathrm{O}_{2}$ toxicity in the absence of other changes in cellular antioxidants. The long-term goal of these studies is to develop a rationale for the protection of neonates from $\mathrm{O}_{2}$ toxicity using dietary manipulations.

\section{MATERIALS AND METHODS}

Cells and culture conditions. Chinese hamster fibroblasts designated HAl (10) were maintained in Eagle's minimal essential medium supplemented with $10 \%$ FCS (HyClone Laboratories, Logan, UT) and penicillin/streptomycin $(100 \mathrm{U} / \mathrm{mL}$ and 0.1 $\mathrm{mg} / \mathrm{mL}$ respectively). Cell cultures were maintained in $37^{\circ} \mathrm{C}$ incubators and routinely checked for mycoplasma contamination as described previously (10).

PUFA incorporation protocol and toxicity studies. Oleic acid ( $>99 \%$ purity), LIN ( $>99 \%$ purity), and EPA ( $>85 \%$ purity), stored in $\mathrm{N}_{2}$-gassed ampules, were purchased from $\mathrm{Nu}$ Chek Prep (Elysian, MN) and used without further purification. To prepare soluble sodium salts of the fatty acids, the contents of the ampules were dissolved in $2 \mathrm{~mL}$ of hexane and approximately $200 \mu \mathrm{L}$ of $6 \mathrm{~N} \mathrm{NaOH}$ was added to the hexane solution, which became opaque. The solution was vortexed and evaporated to dryness under a stream of $\mathrm{N}_{2}$. Five $\mathrm{mL}$ of boiling distilled $\mathrm{H}_{2} \mathrm{O}$ was 
added to the residue and the mixture was vortexed until clear. The solution was sterile filtered and an appropriate amount was added to minimal essential medium containing $10 \%$ FCS supplemented with antibiotics. An aliquot of each fatty acid-enriched medium was taken for gas chromatographic analysis to verify the desired concentration of fatty acid and for vitamin $\mathrm{E}$ analysis before exposing the cells.

Cells $\left(0.75-2 \times 10^{5}\right)$ were plated into $60-\mathrm{mm}$ Petri dishes containing $4 \mathrm{~mL}$ of the control or fatty acid supplemented medium. The cells were grown for $3 \mathrm{~d}$ at $37^{\circ} \mathrm{C}$ incubation to incorporate the desired fatty acid into cellular lipids (11). In selected experiments, $100-\mathrm{mm}$ dishes were used to obtain enough cells for all analyses. Because $100-\mathrm{mm}$ dishes have three times the surface area of $60-\mathrm{mm}$ dishes, the amounts of media and cells were increased by a factor of three when these dishes were used. At the end of $3 \mathrm{~d}$, the media were removed and the cells were either analyzed for fatty acid content, vitamin E content, and cellular antioxidant status or fresh control medium was added before exposure to hyperoxia.

The control and fatty acid-enriched cells were exposed to $95 \%$ $\mathrm{O}_{2}$ and $5 \% \mathrm{CO}_{2}$ at $37^{\circ} \mathrm{C}$ and clonogenic cell survival was assayed at predetermined time intervals as described previously $(10,12)$. Briefly, cells were trypsinized, counted, diluted, and plated into replicate cloning dishes ( 200 to 200000 cells/cloning dish). The cells were allowed to form colonies for 8 to $10 \mathrm{~d}$, at which time they were fixed, stained, and counted using a dissecting microscope. A colony was considered a survivor if it contained at least 50 cells. Dilution replicates containing 50-250 colonies were used for analysis. Cells that detached and floated off the dish during $\mathrm{O}_{2}$ treatment were considered reproductively inactivated for the purpose of analysis (10). Surviving fraction (SF) was calculated using the following equation; $\mathrm{SF}=$ colonies counted/ cells plated. Surviving fractions for cells exposed to $95 \% \mathrm{O}_{2}$ were normalized to the appropriate time-matched control SF in $21 \%$ $\mathrm{O}_{2}$ (SF $95 \% \mathrm{O}_{2} / \mathrm{SF} 21 \% \mathrm{O}_{2}$ ) and plotted on a logarithmic scale as a function of time in $95 \% \mathrm{O}_{2}$. All cells grown in normoxia had surviving fractions of 60 to $90 \%$.

Fatty acid analysis. Cells were harvested using trypsin $(0.1 \%$ in Puck's saline), washed in cold PBS, and pelleted by centrifugation $(400 \times g)$. Six mL of chloroform/methanol $(2 / 1$, vol/vol) were added along with $10-20 \mathrm{nmol}$ of heptadecanoic acid, trinonadecanoin, and diarachidyl phosphatidylcholine as internal standards. One $\mathrm{mL}$ of water was added and the sample was vigorously mixed. The phases were separated by a short centrifugation and the aqueous layer was removed. The chloroform layer was then dried over anhydrous sodium sulfate, and the sample was evaporated to dryness under an argon sweep and reconstituted in $4 \mathrm{~mL}$ of chloroform for lipid fractionation. For the analysis of 0.5 to $1.0 \mathrm{~mL}$ of medium or amounts of other lipid-containing solutions, appropriate amounts of the lipid internal standards were added and the extraction was carried out as described above.

The total lipid extracts were fractionated into neutral lipids (including triglycerides and cholesterol esters), FFA, and phospholipids using a silica gel solid phase extraction column. The column was preconditioned with methanol and methylene chloride. The lipid extract in $4 \mathrm{~mL}$ of chloroform was applied to the column collecting the eluate as the neutral lipid fraction. The FFA fraction was then eluted in $5 \mathrm{~mL}$ of $50 \%$ methanol in methylene chloride, and the phospholipid fraction was eluted in $10 \mathrm{~mL}$ of methanol. All fractions were quantitatively transferred to $5-\mathrm{mL}$ reaction vials for esterification.

The samples were evaporated to dryness under argon. The residue for the neutral lipid and phospholipid fractions were transesterified in $100 \mu \mathrm{L}$ of methylene chloride and $50 \mu \mathrm{L}$ of 0.2 $\mathrm{N}$ trifluoromethylphenyl trimethylammonium hydroxide in methanol at room temperature for $30 \mathrm{~min}$. FFA fractions were esterified in $200 \mu \mathrm{L}$ of $14 \% \mathrm{BF}_{3}$ in methanol at $70^{\circ} \mathrm{C}$ for $1 \mathrm{~h}$. After either type of esterification, $250 \mu \mathrm{L}$ of saturated $\mathrm{NaCl}$ was added and the sample extracted with two $600-\mu \mathrm{L}$ aliquots of petroleum ether. The extracts were combined in a $1-\mathrm{mL}$ reaction vial, evaporated to dryness, and reconstituted in $100 \mu \mathrm{L}$ of isooctane containing an amount of methyl henieicosanoate for determining recovery.

The samples were analyzed using a Hewlett-Packard 5890 gas chromatograph equipped with a split/splitless injector, flame ionization detector, a Hewlett-Packard 3392A integrator/recorder, and a Hewlett-Packard Ultra-2 polymethylsilicone gas chromatography column (Hewlett-Packard Co., Palo Alto, CA). One to $5 \mu \mathrm{L}$ of sample were injected in the splitless mode with a 30 -s split delay. The oven was programmed from $75-200^{\circ} \mathrm{C}$ at $25^{\circ} \mathrm{C} / \mathrm{min}$, then $200-240^{\circ} \mathrm{C}$ at $2^{\circ} \mathrm{C} / \mathrm{min}$, and then $240-300^{\circ} \mathrm{C}$ at $50^{\circ} \mathrm{C} / \mathrm{min}$. Peak areas were recorded by the integrator and quantitation was determined by the area ratio of the fatty acids of interest to the standard fatty acids, correcting for the number of methylene units in each compound.

Vitamin $E$ analysis. Cells were harvested using $0.1 \%$ trypsin and were pelleted by centrifugation at $400 \times g$. The pellet was resuspended in $2 \mathrm{~mL}$ of $\mathrm{N}_{2}$-gassed $50 \mathrm{mM}$ phosphate buffer containing $150 \mathrm{mM} \mathrm{KCl}$ and $0.1 \%$ EDTA, pH 7.4, and $1 \mathrm{~mL}$ of $100 \mathrm{mM}$ SDS in distilled water was added and vortexed. Three $\mathrm{mL}$ of $85 \%$ ethanol and $3 \mathrm{~mL}$ of heptane were added and vortexed for $1 \mathrm{~min}$. The mixture was then centrifuged at $1500 \times$ $g$ to separate the phases, and the heptane layer containing the vitamin $\mathrm{E}$ was removed and stored in $\mathrm{N}_{2}$-gassed tubes at $-20^{\circ} \mathrm{C}$. When ready for analysis, the samples were dried under a stream of $\mathrm{N}_{2}$ and the residue was dissolved in HPLC mobile phase (60.4\% 2-propanol, $20 \%$ acetonitrile, $19 \%$ HPLC $\mathrm{H}_{2} \mathrm{O}, 0.5 \%$ tetraethylamonium hydroxide, $0.1 \%$ acetic acid, $\mathrm{pH} 4.0$ ). Vitamin $\mathrm{E}$ content ( $d l-\alpha$-tocopherol) was analyzed on a ODS HPLC column by the method of Murphy and Kehrer (13) using electrochemical detection. Quantitation was accomplished by comparison of unknown peak heights to a standard curve. Media was extracted and analyzed using the same procedure.

Antioxidant enzyme and total glutathione analysis. Cells were harvested by scraping and cell homogenates were prepared as previously described (14). Total glutathione was determined at $25^{\circ} \mathrm{C}$ by the $5,5^{\prime}$-dithiobis(2-nitrobenzoic acid)-oxidized glutathione reductase recycling assay as described by Anderson (15). Superoxide dismutase activity was determined by the method of Spitz and Oberley (16). Glutathione transferase activity was determined using 1-chloro-2,4-dinitrobenzene as the substrate by the method of Simons and Vander Jagt (17). Catalase activity was determined by the method of Beers and Sizer (18) and was expressed as $\kappa$ units as described by Aebi (19). All biochemical assays were expressed on a per mg protein basis using the method of Lowry et al. (20) to determine total protein content of the cell homogenate.

Statistical analysis. Comparisons between two population means were accomplished using a $t$ test. Comparisons of three or more means were accomplished using analysis of variance with Duncan's new multiple range test. Significance was accepted when $p<0.05$.

\section{RESULTS}

Effect of $25 \mu M L I N$ or EPA exposure on cellular antioxidants and $\mathrm{O}_{2}$ toxicity. Table 1 shows the results of the fatty acid analysis of total media lipids and cellular phospholipids from an experiment in which cells were exposed to $25 \mu \mathrm{M}$ LIN or $25 \mu \mathrm{M}$ EPA for $72 \mathrm{~h}$ at $37^{\circ} \mathrm{C}$. Exposure to $25 \mu \mathrm{M}$ LIN had no effect on growth or cloning efficiency in normoxia. Exposure to $25 \mu \mathrm{M}$ EPA caused no reduction in cloning efficiency, but did cause growth delay as evidenced by an increase from a 14-h doubling time in the control cells to a 17-h doubling time in the EPAtreated cells. The media fatty acid analysis, shown in Table 1 , shows that the only significant change in fatty acid composition, relative to control, occurred in the specific fatty acid that was supplemented, with the exception of a $35 \%$ increase in arachidonic acid (20:4) in the EPA-enriched group. The cellular phos- 
Table 1. Media and cellular phospholipid fatty acid analysis from PUFA-enriched samples

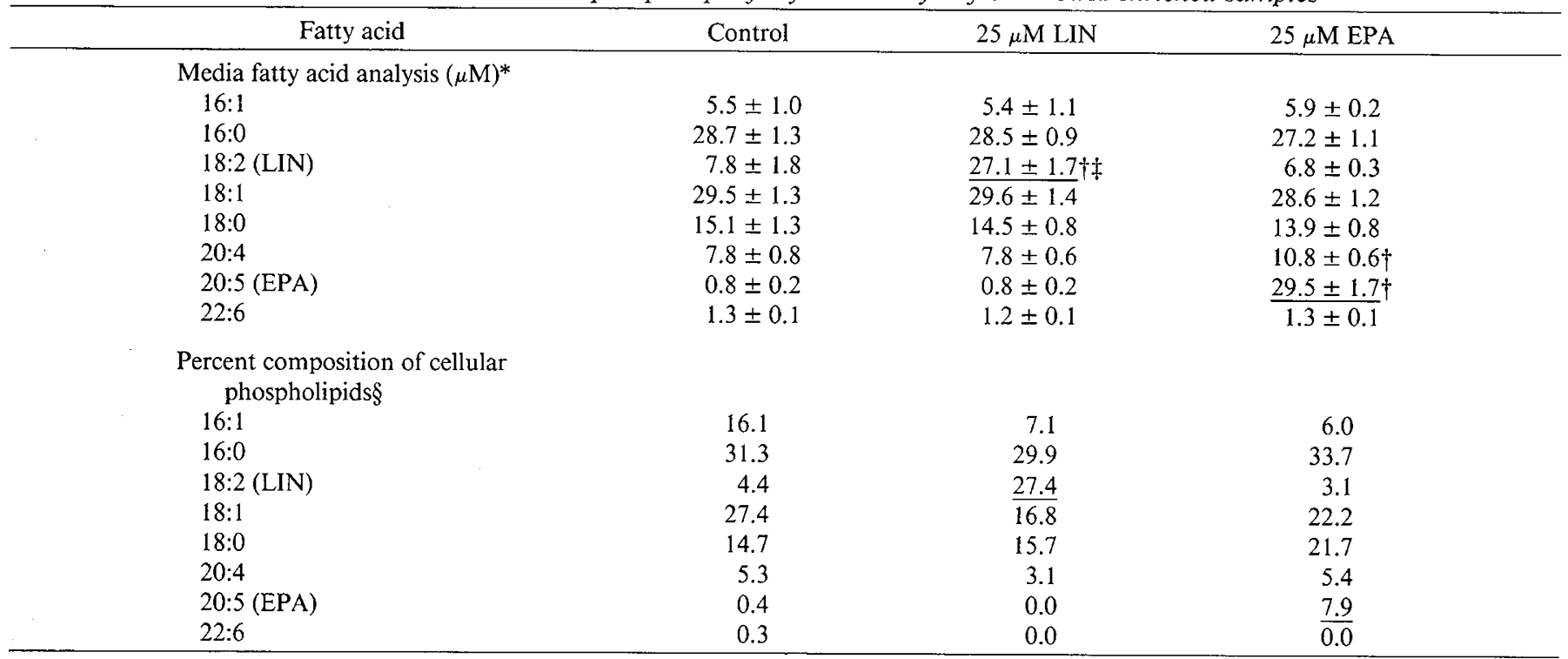

* Values shown are mean values $\pm 1 \mathrm{SD}$ of three $1-\mathrm{mL}$ aliquots of media assayed before exposure to cells.

$\dagger$ Significantly different from the two other groups.

$\$$ Underline indicates the supplemented fatty acid.

$\S$ Values represent analysis of one sample of cells from each group.

pholipid fatty acid analysis, shown in Table 1, shows that a 6fold increase in the percent content of LIN occurred in the cells grown in $25 \mu \mathrm{M}$ LIN and a 19 -fold increase in the percent composition of EPA occurred in the cells grown in $25 \mu \mathrm{M}$ EPA.

After the exposure of cells to PUFA-supplemented and control media, the media were removed, the cells were washed, and some dishes were collected for antioxidant analysis and the remainder were exposed to $95 \% \mathrm{O}_{2}$. Table 2 shows the results of the cellular antioxidant analysis. Total glutathione was significantly increased in LIN-treated cells relative to control or EPA-treated cells. No other cellular antioxidant tested was significantly altered by treatment with LIN or EPA.

Figure 1 shows the survival data for the LIN- and EPA-treated cells after exposure to $95 \% \mathrm{O}_{2}$. These data were collected on the same cohort of cultures analyzed for phospholipid fatty acid composition in Table 1. Between 0 and $45 \mathrm{~h}$, LIN-treated cells demonstrated a pattern of clonogenic inactivation similar to control, but manifested significant sensitization to $95 \% \mathrm{O}_{2}$ from 56 to $75 \mathrm{~h}$ of $\mathrm{O}_{2}$ exposure (Fig. 1, upper panel). EPA-treated cells were significantly more sensitive to $\mathrm{O}_{2}$ toxicity at every time point after $24 \mathrm{~h}$ (Fig. 1, lower panel). The time in $95 \% \mathrm{O}_{2}$ necessary to clonogenically inactivate $90 \%$ of the LIN-treated cells was reduced by only $5 \mathrm{~h}$ relative to control cells, indicating a slight sensitization to $\mathrm{O}_{2}$-induced clonogenic inactivation. In contrast, the time to reach $90 \%$ clonogenic inactivation in the EPA-treated cells was reduced by $18 \mathrm{~h}$, relative to control. These results indicate that the magnitude of EPA-induced sensitization to $\mathrm{O}_{2}$ toxicity was greater than the sensitization mediated by incorporation of LIN using equal molar amounts $(25 \mu \mathrm{M})$ of fatty acid in the pretreatment media.
Effect of $25 \mu M L I N$ or 2 and $4 \mu M$ EPA on vitamin $E$ content and $\mathrm{O}_{2}$ toxicity. Because $25 \mu \mathrm{M}$ EPA caused some growth delay in $21 \% \mathrm{O}_{2}$, the subsequent experiments used a $72-\mathrm{h}$ incorporation period with either $2 \mu \mathrm{M}$ EPA or $4 \mu \mathrm{M}$ EPA in addition to 25 $\mu \mathrm{M}$ LIN. The control and fatty acid-enriched media (LIN, EPA) were analyzed for vitamin $\mathrm{E}$ and fatty acid content before incubation with cells. The cells were also assayed for fatty acid and vitamin $E$ content after incubation with media. In the experiment shown in Tables 3 and 4, the LIN content of the LIN-enriched medium was $28.2 \mu \mathrm{M}$ and the EPA content of the EPA-enriched medium was $2.0 \mu \mathrm{M}$ and $4.2 \mu \mathrm{M}$ as determined by gas chromatography. As shown in Table 3, the vitamin E content of the fatty acid-supplemented media and cells exposed to those media were not statistically different from control. After exposure to these fatty acid-supplemented media, there were no reductions in clonogenicity detected, nor was there any growth delay detected in any group. These results show that this fatty acid incorporation protocol produced no adverse effects on cell viability and did not alter vitamin E content.

The percent fatty acid composition of the phospholipids and neutral lipids (triacylglycerols and cholesterol esters) isolated from the cells after the incorporation interval appears in Table 4. LIN-supplemented cells demonstrated a 7-fold iricrease in the percent composition of LIN in the phospholipid fraction, relative to control. Two and $4 \mu \mathrm{M}$ EPA-supplemented cells demonstrated 7- and 13-fold increases, respectively, in the percent composition of EPA in the phospholipid fraction, relative to control. In LINtreated cells, increases in percent composition of LIN were offset by significant decreases in $16: 1$ and 18:1. In $4 \mu \mathrm{M}$ EPA-treated cells, significant decreases in 18:1 and 16:1 also occurred, relative

Table 2. Cellular antioxidant analysis from PUFA-enriched cultures*

\begin{tabular}{|c|c|c|c|c|c|c|}
\hline & \multirow{2}{*}{$\begin{array}{c}\mathrm{GSH} \\
(\mu \mathrm{g} / \mathrm{mg})\end{array}$} & \multirow{2}{*}{$\begin{array}{c}\mathrm{GST} \\
(\mathrm{mU} / \mathrm{mg})\end{array}$} & \multirow{2}{*}{$\begin{array}{c}\text { CAT } \\
\left(\mathrm{m}_{\kappa} \mathrm{U} / \mathrm{mg}\right)\end{array}$} & \multicolumn{3}{|c|}{ Superoxide dismutase $(\mathrm{U} / \mathrm{mg})$} \\
\hline & & & & Total & MnSOD & CuZnSOD \\
\hline Control $(n=6)$ & $3.7 \pm 0.6$ & $333 \pm 41$ & $43 \pm 4$ & $43 \pm 4$ & $13 \pm 2$ & $30 \pm 5$ \\
\hline $25 \mu \mathrm{M} \mathrm{EPA}(n=3)$ & $3.6 \pm 0.5$ & $361 \pm 30$ & $42 \pm 7$ & $34 \pm 4$ & $10 \pm 3$ & $24 \pm 5$ \\
\hline
\end{tabular}

* Abbreviations: GSH, total glutathione; CAT, catalase activity; CuZnSOD, MnSOD, CuZn and Mn superoxide dismutase activity; GST, glutathione transferase activity; $\mathrm{mg}=\mathrm{mg}$ of protein. Values shown are means $\pm 1 \mathrm{SD}$ of at least three separately prepared homogenates.

$\uparrow$ Significantly different from all other groups $(p<0.05)$. 

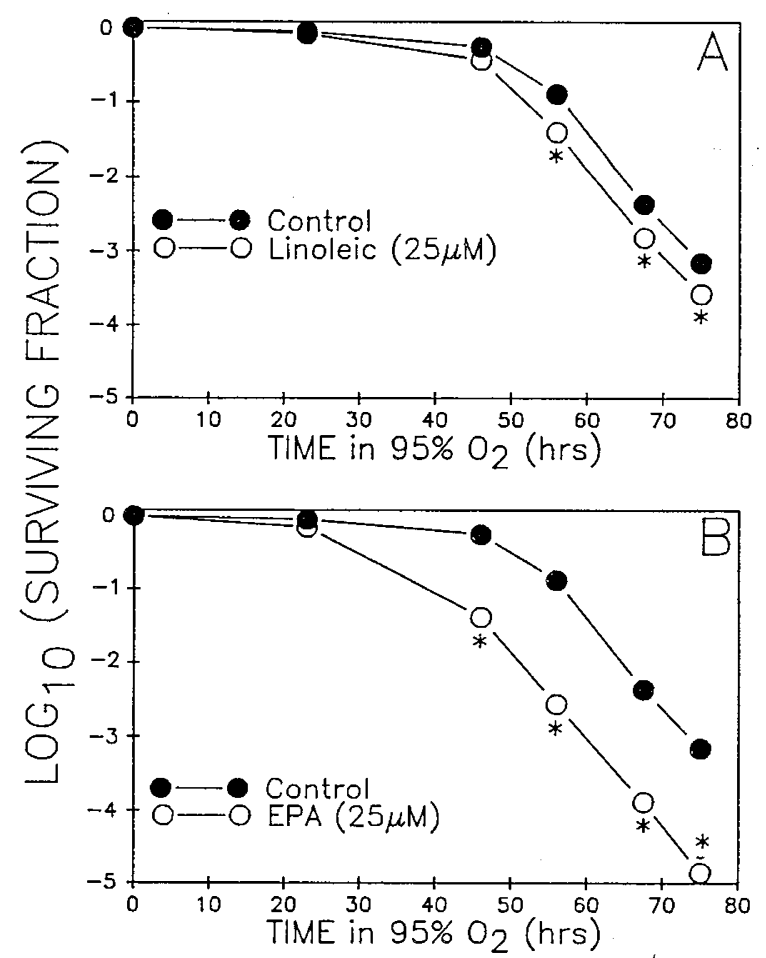

Fig. 1. Survival data for PUFA-enriched cultured cells exposed to $95 \% \mathrm{O}_{2}$. These data were gathered in the same experiment as the phospholipid analysis shown in Table 1. Surviving fraction is plotted on a $\log _{10}$ scale. Each symbol represents the mean of three separately treated cultures, and the errors ( $\pm 1 \mathrm{SD}$ ) appear when larger than the point. Asterisks mark those points that are significantly different from control $(p<0.05)$.

Table 3. Vitamin E analysis of PUFA-enriched media and cells*

\begin{tabular}{ccc}
\hline Treatment group & $\begin{array}{c}\text { Medium } \\
(\mathrm{ng} / \mathrm{mL})\end{array}$ & $\begin{array}{c}\text { Cells } \\
\left(\mathrm{ng} / 10^{6} \text { cells }\right)\end{array}$ \\
\hline Control & $5.0 \pm 2.4$ & $1.5 \pm 0.6$ \\
$25 \mu \mathrm{M} \mathrm{LIN}$ & $8.2 \pm 4.3$ & $1.8 \pm 0.4$ \\
$2 \mu \mathrm{M}$ EPA & $6.9 \pm 3.4$ & $1.5 \pm 0.3$ \\
$4 \mu \mathrm{M} \mathrm{EPA}$ & $6.9 \pm 1.4$ & $1.4 \pm 0.4$ \\
\hline
\end{tabular}

* Values shown are mean values \pm 1 SD. Media data were gathered using three $1-\mathrm{mL}$ samples and cell data were gathered using three samples consisting of two $60-\mathrm{mm}$ cultures per sample. No significant differences exist between treatment groups $(p<0.05)$. Media were assayed before exposure to cells.

to control. In $2 \mu \mathrm{M}$ EPA-treated cells, significant changes in percent composition of fatty acids other than EPA did not occur. Similar changes in the percent composition of LIN and EPA were also seen in the neutral lipids from cells enriched with these fatty acids.

Because percent composition may not accurately reflect the absolute amount of fatty acids incorporated into cells, we calculated the fatty acid changes as nmol/ $10^{6}$ cells (Table 4 ). The total amount of fatty acids $/ 10^{6}$ cells recovered from the phospholipid fraction was similar for all treatment groups. However, the total amount of fatty acids $/ 10^{6}$ cells recovered from the neutral lipid fraction was significantly elevated 4 -fold in the $25 \mu \mathrm{M}$ LINtreated cells and 2-fold in the $4 \mu \mathrm{M}$ EPA-treated cells, relative to control. Overall, the same significant differences that occurred in the individual fatty acids when the data were expressed as percent composition were also noted when the data were expressed as nmol $/ 10^{6}$ cells (Table 4 ). However, when the data were expressed as $\mathrm{nmol} / 10^{6}$ cells, fewer of the differences were statistically significant and some actual increases in the quantity of specific fatty acids other than the supplemented fatty acid were noted in the neutral lipid analysis. The percent composition (Table 4 ) of the neutral lipid in the $25-\mu \mathrm{M}$ LIN group showed $16: 1,16: 0,18: 1$, and 18:0 were reduced, relative to control. However, the absolute number of $\mathrm{nmol} / 10^{6}$ cells of these fatty acids in the neutral lipids of the $25 \mu \mathrm{M}$ LIN-treated group (Table 4), was actually increased, relative to control. These observations point to the importance of expressing fatty acid incorporation data both as percent composition and absolute quantity.

Figure 2 shows the survival data from cells pretreated with 25 $\mu \mathrm{M}$ LIN, $2 \mu \mathrm{M}$ EPA, or $4 \mu \mathrm{M}$ EPA and exposed to $95 \% \mathrm{O}_{2}$. These results were obtained in the same cohort of cultures analyzed for fatty acid content in Table 4 . The upper panel shows that LIN-treated cells responded identically to control at 24 and $41 \mathrm{~h}$ of $\mathrm{O}_{2}$ and demonstrated a slight but significant sensitization to $\mathrm{O}_{2}$ toxicity at $53 \mathrm{~h}$ of exposure. The lower panel shows that EPA-treated cells were significantly more sensitive to $\mathrm{O}_{2}$ toxicity at every point tested, relative to $\mathrm{HA1}$. The time in $95 \% \mathrm{O}_{2}$ needed to clonogenically inactivate $90 \%$ of the cells was reduced by $4 \mathrm{~h}$ in the $2 \mu \mathrm{M}$ EPA-enriched cells and by $8 \mathrm{~h}$ in the $4 \mu \mathrm{M}$ EPA-enriched cells, relative to control. Also, at 24 and $41 \mathrm{~h}, 4$ $\mu \mathrm{M}$ EPA-treated cells were significantly more sensitive to $\mathrm{O}_{2}$ toxicity than cells treated with $2 \mu \mathrm{M}$ EPA.

Effect of $25 \mu \mathrm{M}$ oleic acid exposure on $\mathrm{O}_{2}$ toxicity. Table 5 shows the results of the fatty acid analysis of total cellular lipids from an experiment in which cells were exposed to $25 \mu \mathrm{M}$ oleic acid for $72 \mathrm{~h}$ at $37^{\circ} \mathrm{C}$. Exposure to oleic acid had no effect on growth or cloning efficiency in normoxia. The analysis of total fatty acid composition revealed a statistically significant 2.5 -fold increase in oleic acid content in the absence of changes in any other specific fatty acid (Table 5).

These control and oleic acid-enriched cultures were washed, complete fresh control medium was added, and then the cultures were exposed to $95 \% \mathrm{O}_{2}$. The survival results appear in Figure 3. In contrast to the results with PUFA-enriched cells (Figs. 1 and 2), the oleic acid-enriched cells were significantly more resistant than control to $\mathrm{O}_{2}$ toxicity at 51,72 , and $98 \mathrm{~h}$ of $95 \%$ $\mathrm{O}_{2}$ exposure. In this experiment, the time in $95 \% \mathrm{O}_{2}$ needed to clonogenically inactivate $90 \%$ of the cells was increased by $10 \mathrm{~h}$ in the oleic acid-enriched cultures, relative to control.

\section{DISCUSSION}

The lipid composition of tissues and cells has been shown to be amenable to alterations by dietary manipulation (11). Furthermore, because lipids provide a substrate that readily interacts with reactive $\mathrm{O}_{2}$ species, their manipulation may provide a means of modifying biologically significant responses to oxidative stress, such as $\mathrm{O}_{2}$ toxicity in neonates. However, the effects of lipids on the injury process associated with $\mathrm{O}_{2}$ toxicity has been a subject of some controversy.

Previous studies in animals and cell cultures have shown that treatments that decrease PUFA percent composition of cellular lipids sensitize cells to $\mathrm{O}_{2}$ toxicity $(6,21)$. Other studies have shown that treatments that increase PUFA percent composition result in protection from $\mathrm{O}_{2}$ toxicity (6-9). These studies all support the hypothesis that PUFA play a protective role during exposure to hyperoxia. The proposed mechanism of this protection involves PUFA reacting with and thereby diverting reactive $\mathrm{O}_{2}$ species from interacting with more critical biomolecules (6).

In contrast, other studies in cells, animals, and human neonates have found an association between increased PUFA and increased sensitivity to $\mathrm{O}_{2}$ toxicity and hydrogen peroxide (2225). Also, some studies have found that decreasing PUFA was associated with decreased sensitivity to $\mathrm{O}_{2}$ toxicity and hydrogen peroxide $(24,26)$. These investigations appear to support the hypothesis that increasing cellular PUFA content is associated with increased sensitivity to $\mathrm{O}_{2}$ toxicity and $\mathrm{H}_{2} \mathrm{O}_{2}$, possibly by increasing lipid peroxidation $(23,24)$.

Although it is not exactly clear why these studies have yielded 
Table 4. Phospholipid and neutral lipid analysis from PUFA-enriched samples*

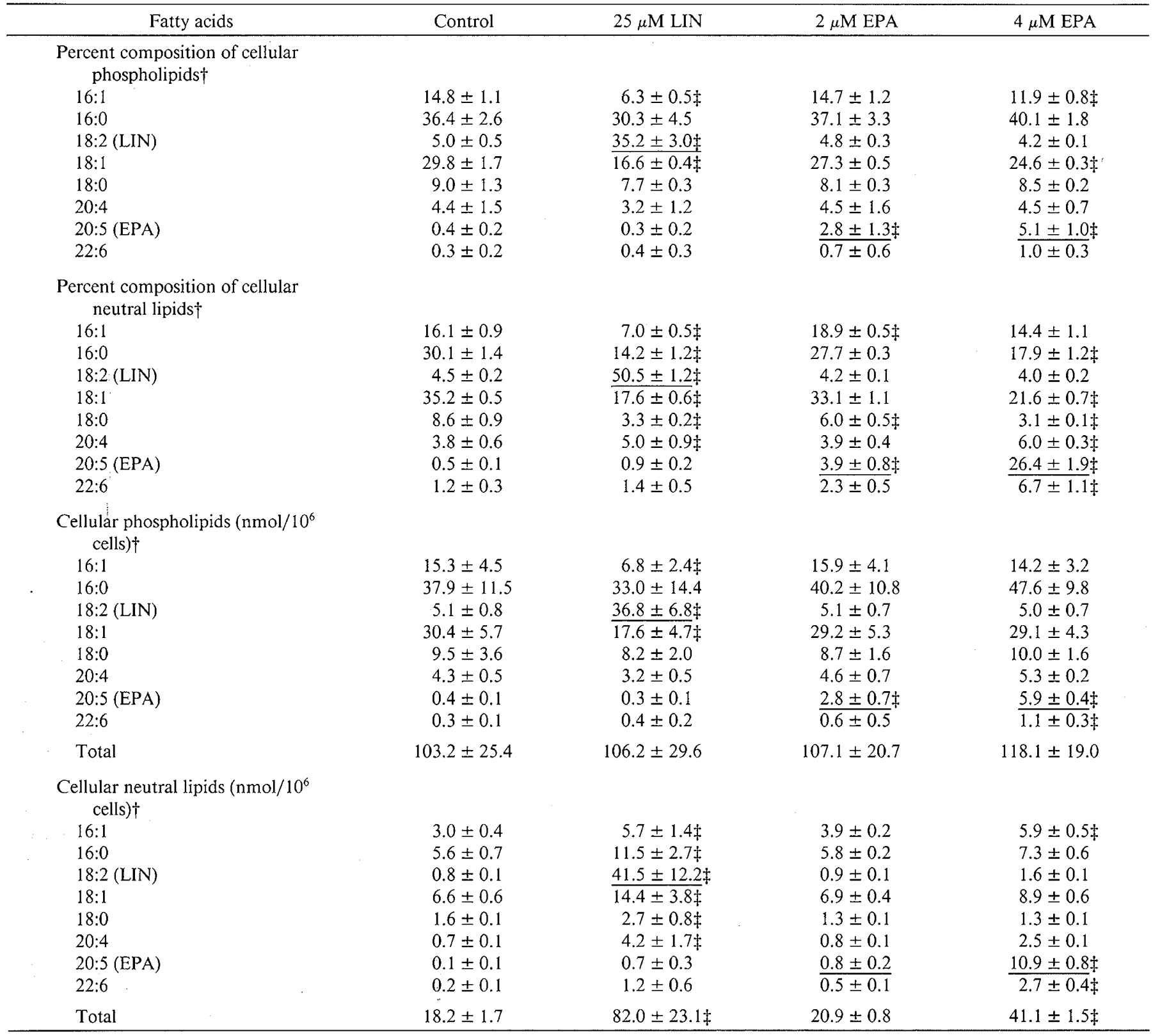

* Values represent mean values \pm 1 SD of three separately prepared and analyzed samples. Underline indicates the supplemented fatty acid. $\dagger$ Enriched media contained $28.2 \mu \mathrm{M}$ LIN, $2.0 \mu \mathrm{M}$ EPA, and $4.2 \mu \mathrm{M}$ EPA as determined by gas chromatography before exposure to cells. $\$$ Significantly different from control $(p<0.05)$.

conflicting results, it is common for various lipid preparations commercially available to differ significantly in composition, particularly vitamin E content, fatty acid carbon chain length, extent of unsaturation, and placement of unsaturations. Because each specific fatty acid as well as other components in these mixtures is potentially a different pharmacologic agent, each needs to be considered for its properties alone or in combination with other constituents. Therefore, these differences in the composition of lipid preparations may account for the differences in $\mathrm{O}_{2}$ response seen with different nutritional supplements designed to alter PUFA content. The animal studies using LIN- and EPAenriched diets, in fact, used mixtures of various fatty acids. Also, most reports express fatty acid enrichment data on the basis of percent composition and not absolute amounts of fatty acid incorporated. The results shown in Table 4 show that different conclusions can be drawn from a single set of fatty acid incorporation data expressed using these two different methods. This could also represent a possible source of variability between conclusions in studies of cytotoxicity. One could speculate that with respect to lipid peroxidation events, the absolute quantity of individual fatty acids could be more relevant than percent composition changes because it is the absolute amount that most directly relates to injurious or protective events. Finally, the end point of toxicity could have a differential influence on the conclusions drawn from the various results obtained. A measure of cellular reproductive integrity (clonogenicity) was chosen as the relevant end point for toxicity studies in the present work, because the capability of cells to divide is integrally related to their ability to survive cytotoxic insult.

The initial studies documented the specificity of the fatty acid media enrichment protocol (Table 1), that LIN and EPA from enriched media were incorporated into cellular lipids (Tables 1 and 4), and that cellular antioxidant status of PUFA-treated cells was similar to control (Tables 2 and 3). These results support the conclusion that only one fatty acid in the media was altered and that cellular antioxidants were not affected by this change in 


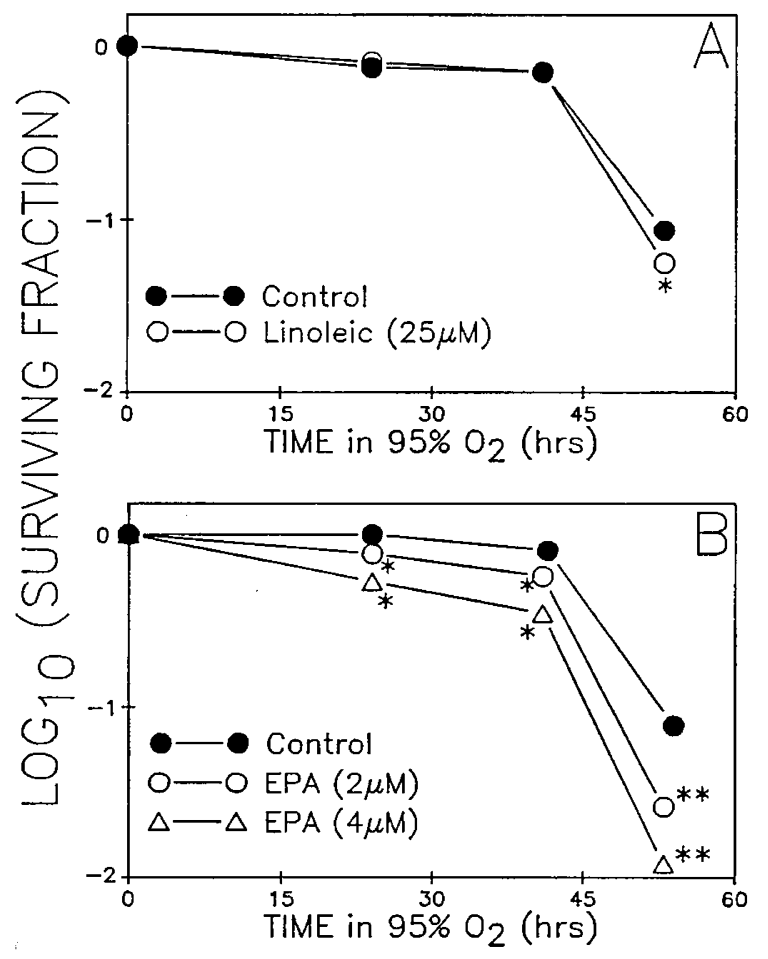

Fig. 2. Survival data for PUFA-enriched cultured cells exposed to $95 \% \mathrm{O}_{2}$. These data were gathered in the same experiment as the fatty acid and vitamin $E$ analyses shown in Tables 3 and 4 . Surviving fraction is plotted on a $\log _{10}$ scale. Each point represents the mean of three separately treated cultures, and errors ( $\pm 1 \mathrm{SD}$ ) appear when larger than the symbol. Single asterisks $\left(^{*}\right)$ designate points that are significantly different from control and each other. Double asterisks $\left({ }^{* *}\right)$ designate points that are different from control but not each other.

Table 5. Total lipid analysis of cells enriched with oleic acid

Total fatty acid analysis (nmol $/ 10^{6}$ cells)*

\begin{tabular}{lcc}
\hline Fatty acids & \multicolumn{1}{c}{ Control } & $25 \mu \mathrm{M}$ Oleic acid \\
\hline $16: 1$ & $16.1 \pm 0.3$ & $16.6 \pm 1.1$ \\
$16: 0$ & $51.4 \pm 2.9$ & $49.2 \pm 3.6$ \\
$18: 2$ (LIN) & $3.8 \pm 0.4$ & $3.5 \pm 0.9$ \\
$18: 1$ (Oleic) & $18.7 \pm 1.4$ & $47.4 \pm 2.7 \dagger$ \\
$18: 0$ & $15.9 \pm 1.6$ & $14.6 \pm 1.3$ \\
$20: 4$ & $3.3 \pm 0.2$ & $3.7 \pm 0.3$ \\
$20: 5$ (EPA) & $0.2 \pm 0.2$ & $0.2 \pm 0.2$ \\
$22: 6$ & $0.7 \pm 0.1$ & $0.4 \pm 0.4$ \\
Total & $110.0 \pm 5.8$ & $135.6 \pm 5.9 \dagger$ \\
\hline
\end{tabular}

* Values represent mean values $\pm 1 \mathrm{SD}$ of three separately prepared and analyzed samples. Enriched media contained $31 \mu \mathrm{M}$ more oleic acid than control media as determined by gas chromatography. Lipids in this experiment were not fractionated and analysis represents a total lipid analysis of all cellular components.

$\dagger$ Significantly different from control $(p<0.05)$.

such a way as to explain sensitization to $\mathrm{O}_{2}$ toxicity. However, in cells exposed to $25 \mu \mathrm{M}$ LIN, $25 \mu \mathrm{M}$ EPA, and $4 \mu \mathrm{M}$ EPA, increases in LIN and EPA were associated with changes in some fatty acids other than the specific fatty acids of interest (Tables 1 and 4). These types of changes in other fatty acids in cells enriched with LIN have been reported by other authors (11). However, in cells exposed to low-dose EPA $(2 \mu \mathrm{M})$, only the specific fatty acid of interest was changed, indicating that at this dose with this particular fatty acid no nonspecific changes in cellular lipids occurred. No nonspecific changes in fatty acid content were detected in oleic acid-enriched cells (Table 5).

The LIN- and EPA-supplemented cells were significantly more

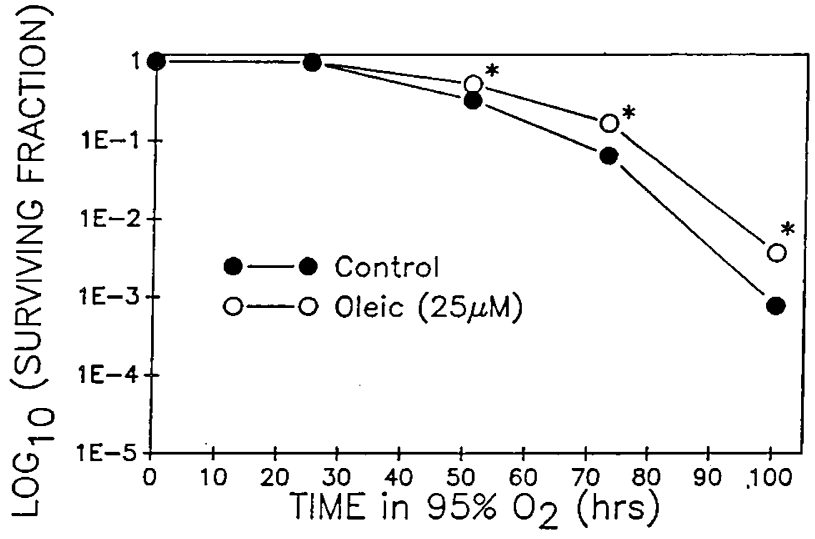

Fig. 3. Survival data for oleic acid-enriched cultured cells exposed to $95 \% \mathrm{O}_{2}$. These data were gathered in the same experiment shown in Table 5. Surviving fraction is plotted on a $\log _{10}$ scale. Each point represents the mean of three separately treated cultures, and errors ( $\pm 1 \mathrm{SD}$ ) appear when larger than the symbol. Single asterisks designate points that are significantly different from control $(p<0.05)$.

sensitive to $\mathrm{O}_{2}$ toxicity, relative to unsupplemented control cells. Also, at equimolar concentrations in the incorporation media $(25 \mu \mathrm{M})$, EPA appeared to be a more potent sensitizer to $\mathrm{O}_{2}$ toxicity than LIN (Fig. 1). Furthermore, there was a doseresponse relationship between increasing EPA content and increased sensitivity to $\mathrm{O}_{2}$ toxicity (Table 4, Fig. 2). Finally, changes in fatty acids other than the fatty acid of interest are not likely to be responsible for $\mathrm{O}_{2}$ sensitivity because exposure to $25 \mu \mathrm{M}$ LIN caused more changes in other fatty acids and less $\mathrm{O}_{2}$ sensitization than did $2 \mu \mathrm{M}$ and $4 \mu \mathrm{M}$ EPA (Table 4, Fig. 2). In fact, $2-\mu \mathrm{M}$ EPA exposure caused no nonspecific changes in absolute quantities of other fatty acids yet caused significant sensitization to $\mathrm{O}_{2}$ toxicity (Table 4, Fig. 2). These results point to the conclusion that each specific fatty acid has unique properties that impact differently upon $\mathrm{O}_{2}$ sensitivity. The results using this model also suggest that PUFA (LIN and EPA) incorporated into phospholipids and neutral lipids do not directly scavenge reactive $\mathrm{O}_{2}$ species in a manner that protects cells against $\mathrm{O}_{2}$ toxicity.

The apparent differences between these data and studies that conclude that PUFA is protective could be due to several differences that exist between the experimental designs and models used in the various studies. Depending on the timing of the PUFA treatment and $\mathrm{O}_{2}$ exposure, different fatty acid pools (free, phospholipid, and neutral lipid) could be influenced differently. Differences in quantities of various fatty acids in various pools could determine the outcome of $\mathrm{O}_{2}$ effects. If LIN or EPA are having a beneficial effect in the animal models because they suppress immune cell-mediated inflammatory damage $(27,28)$, this type of protection would not occur in cultured cells exposed to $\mathrm{O}_{2}$ in the absence of white cells. Also, because the animals were receiving complex lipid diets, some dietary constituent other than, or acting together with, the fatty acid of interest may have altered the animals' susceptibility to $\mathrm{O}_{2}$ toxicity. Finally, the lipid diets used in the animal models may have some physiologic effect on parameters such as pulmonary hemodynamics that determine responses to $\mathrm{O}_{2}$ toxicity not present in cultured cells.

In contrast to the results with the PUFA (LIN and EPA), enrichment of cellular lipids with a monosaturated fatty acid (oleic acid) rendered cells significantly more resistant to $\mathrm{O}_{2}$ toxicity relative to control (Fig. 3). This $\mathrm{O}_{2}$ resistance was noted in the absence of any alteration in other specific fatty content (Table 5). Because oleic acid contains one double bond, whereas LIN and EPA contain two and five double bonds, respectively, it is tempting to speculate that the absolute number of double bonds introduced into cells may impact upon $\mathrm{O}_{2}$ sensitivity. DBI (mol of double bonds/mol of total fatty acids) calculations from 
the $\mathrm{nmol} / 10^{6}$ cells data in Tables 4 and 5 indicate that control has a DBI of $0.60 \pm 0.23$, whereas the $25 \mu \mathrm{M}$ oleic-, $25 \mu \mathrm{M}$ LIN, $2 \mu \mathrm{M}$ EPA-, and $4 \mu \mathrm{M}$ EPA-enriched cells have DBI equal to $0.66,1.30,0.89$, and 1.32 , respectively. Twenty-five $\mu \mathrm{M}$ LIN(DBI 1.30) and $4 \mu \mathrm{M}$ EPA- (DBI 1.32) enriched cells have similar double bond indices, and yet EPA causes more sensitization to $\mathrm{O}_{2}$ toxicity (Fig. 2). Furthermore, the oleic acid-enriched cells' DBI is similar to control, and yet these cells were protected from $\mathrm{O}_{2}$ toxicity (Fig. 3). These results lead us to conclude that DBI (and therefore the absolute number of double bonds) does not accurately predict sensitization or protection from $\mathrm{O}_{2}$ toxicity. This leads to the concept that chemical characteristics specific to each fatty acid (containing double bonds) are the most important determinants of $\mathrm{O}_{2}$ sensitivity after cellular fatty acid enrichment. These data also reinforce the concept that each fatty acid represents a potentially different pharmacologic agent that must be considered for its own properties.

It is intriguing to speculate that the mechanism(s) involved in sensitization to $\mathrm{O}_{2}$ toxicity seen with LIN- or EPA-enriched cells may include alterations in the process of lipid peroxidation. Because LIN and EPA are good substrates upon which lipid peroxidation can be initiated and propagated, increasing the content of these fatty acids in cells may increase the amount of peroxidized lipid formed during exposure to hyperoxia $(23,29-$ 31 ). Furthermore, highly reactive cytotoxic by-products formed as a result of lipid peroxidation, such as hydroperoxides and lipid aldehydes $(1,4,12,23,26)$, might occur in greater abundance in hyperoxia-exposed PUFA-treated cells and account for the increased sensitization to $\mathrm{O}_{2}$ toxicity seen with LIN and EPA supplementation. It is also interesting to speculate that different fatty acids when peroxidized could give rise to by-products that differ in cytotoxicity. This could explain differences in sensitization produced by different fatty acids. Conversely, incorporation of monosaturated fatty acids has been shown to result in decreased lipid peroxidation (as assayed by the thiobarbituric acid reactive substance assay) and decreased sensitivity to oxidative stress $(24,26)$ including hyperoxia $(26$, this article). These results lead to the speculation that monosaturated fatty acid incorporation could protect against $\mathrm{O}_{2}$ toxicity by reducing lipid peroxidation and the quantity or spectrum of cytotoxic byproducts. Our results do suggest that altering the substrate upon which lipid peroxidation occurs may alter $\mathrm{O}_{2}$ injury. This leaves open the possibility that manipulations of lipid peroxidation via specific fatty acid treatments that modify the production of toxic peroxidation by-products may provide a useful tool in attempts to pharmacologically alter clinically significant $\mathrm{O}_{2}$ toxicity.

Acknowledgments. The authors thank Donna T. Adams, Lynn Pearson, and C. Michael Sherman for technical assistance and Dr. C. Patrick Burns and Brett A. Wagner for helpful suggestions concerning the design of the fatty acid incorporation protocol. The authors also thank Louis P. Baron for administrative assistance, data compilation, and manuscript preparation.

\section{REFERENCES}

1. Jamieson D 1989 Oxygen toxicity and reactive oxygen metabolites in mammals. Free Radic Biol Med 7:87-108

2. Turrens JF, Freeman BA, Crapo JD 1982 Hyperoxia increases $\mathrm{H}_{2} \mathrm{O}_{2}$ release by lung mitochondria microsomes. Arch Biochem Biophys 217:411-421

3. Turrens JF, Freeman BA, Levitt JG, Crapo JD 1982 The effect of hyperoxia on superoxide production by lung submitochondrial particles. Arch Biochem Biophys 217:401-410

4. Joenje H 1989 Genetic toxicity of oxygen. Mutation Res 219:193-208

5. Clements JA 1971 Comparative lipid chemistry of lungs. Arch Intern Med 127:387-389

6. Sosenko IRS, Innis SM, Frank L 1988 Polyunsaturated fatty acids and protection of newborn rats from oxygen toxicity. J Pediatr 112:630-637

7. Sosenko IRS, Innis SM, Frank L 1989 Menhaden fish oil, n-3 polyunsaturated fatty acids, and protection of newborn rats from oxygen toxicity. Pediatr Res 25:399-404

8. Dennery PA, Kramer CM, Alpert SE 1990 Effect of fatty acid profiles on the susceptibility of cultured rabbit tracheal epithial to hyperoxic injury. Am J Respir Cell Mol Biol 3:137-144

9. Sosenko IRS, Innis SM, Frank L 1991 Intralipid protects against oxygen toxicity in newborn rats without increasing lung levels of cyclooxygenase and lipoxygenase mediators. Pediatr Res 29:304A(abstr)

10. Spitz DR, Elwell JH, Sun Y, Oberley LW, Oberley TD, Sullivan SJ, Roberts RJ 1990 Oxygen toxicity in control and $\mathrm{H}_{2} \mathrm{O}_{2}$-resistant Chinese hamster fibroblast cell lines. Arch Biochem Biophys 279:249-260

11. Spector AA, Yorek MA 1985 Membrane lipid composition and cellular function. J Lipid Res 26:1015-1035

12. Sullivan SJ, Roberts RJ, Spitz DR 1991 Replacement of media in cell culture alters oxygen toxicity: possible role of lipid aldehydes and glutathione transferases in $\mathrm{O}_{2}$ toxicity. J Cell Physiol 147:427-433

13. Murphy ME, Kehrer JP 1987 Simultaneous measurement of tocopherols and tocopheryl quinones in tissue fractions using high-performance liquid chromatography with redox-cycling electrochemical detection. J Chromatogr 421:71-82

14. Spitz DR, Malcolm RR, Roberts RJ 1990 Cytotoxicity and metabolism of 4hydroxy-2-nonenal and 2-nonenal in $\mathrm{H}_{2} \mathrm{O}_{2}$-resistant cell lines. Biochem $\mathrm{J}$ 267:453-459

15. Anderson ME 1985 Tissue glutathione. In: Greenwald RA (ed) Handbook of Methods for Oxygen Radical Research. CRC Press, Boca Raton, FL, pp 317-323

16. Spitz DR, Oberley LW 1989 An assay for superoxide dismutase activity in mammalian tissue homogenates. Anal Biochem 179:8-18

17. Simons PC, Vander Jagt DL 1977 Purification of glutathione s-transferases from human liver by glutathione-affinity chromatography. Anal Biochem $82: 334-341$

18. Beers RF, Sizer IW 1952 A spectrophotometric method for measuring the breakdown of $\mathrm{H}_{2} \mathrm{O}_{2}$ by catalase. J Biol Chem 195:133-140

19. Aebi H 1984 Catalase in vitro. In: Methods in Enzymology, Vol. 105. Academic Press, New York, pp 121-126

20. Lowry OH, Rosebrough NJ, Farr AL, Randall RJ 1951 Protein measurement with the Folin phenol reagent. J Biol Chem 193:265-275

21. Kehrer JP, Autor AP 1978 The effect of dietary fatty acids on the composition of adult rat lung lipids: relationship to oxygen toxicity. Toxicol Appl Pharmacol 44:423-430

22. Schatte CL, Mathias MM 1982 Effect of dietary fat on pulmonary enzymes and toxicity during normobaric hyperoxia. Aviat Space Environ Med 53:629-632

23. Freeman BA, Young SL, Crapo JD 1983 Liposome-mediated augmentation of superoxide dismutase in endothelial cells prevents oxygen injury. J Biol Chem 258:12534-12542

24. Hart GM, Tolson JK, Block ER 1991 Supplemental fatty acids alter lipid peroxidation and oxidant injury in endothelial cells. Am J Physiol 260:L481L488

25. Hammerman G, Aramburo MJ 1988 Decreased lipid intake reduces morbidity in sick premature neonates. J Pediatr 113:1083-1088

26. Block ER 1988 Interaction between oxygen and cell membranes: modification of membrane lipids to enhance pulmonary artery endothelial cell tolerance to hyperoxia. Exp Lung Res 14:937-958

27. Fisher M, Levine PH, Weiner BH, Johnson MH, Doyle EM, Ellis PA, Hoogasian JJ 1990 Dietary n-3 fatty acid supplementation reduces superoxide production and chemiluminescence in a monocyte-enriched preparation of leukocytes. Am J Clin Nutr 51:804-808

28. Hubbard NE, Somers SD, Erickson KL 1991 Effect of dietary fish oil on development and selected functions or murine inflammatory macrophages. J Leukocyte Biol 49:592-598

29. Benedetti AM, Comporti M, Esterbauer H 1980 Identification of 4-hydroxynonenal as a cytotoxic product originating from the peroxidation of liver microsomal lipids. Biochim Biophys Acta 620:281-296

30. Burns CP, Wagner BA 1991 Heightened susceptibility of fish oil polyunsaturate-enriched neoplastic cells to ethane generation during lipid peroxidation. J Lipid Res 32:79-87

31. Esterbauer H, Zollner H, Schaur RJ 1988 Hydroxyalkenals: cytotoxic products of lipid peroxidation. ISI Atlas Sci Biochem 1:311-317 